\title{
KORPORATIVNO UPRAVLJANJE I EKONOMIJA TREĆEG PUTA
}

\author{
Valentina Vinšalek Stipić, univ.spec.oec., v.pred. \\ Veleučilište „Nikola Tesla“ u Gospiću \\ Bana Ivana Karlovića 16, 53000 Gospić \\ Telefon: +385 53652 305, e-mail: valentinavinsalek@gmail.com
}

\section{SAŽETAK}

Suvremeno globalno okruženje zahtijeva od korporativnog menadžmenta primjenu novih način upravljanja radi ostvarivanja i zadržavanja konkurentske prednosti. Sve interesne skupine moraju imati zajednički cilj kako bi se ostvarilo opće zadovoljstvo. Poduzećima ne smije više jedini cilj biti ostvarivanje profita, nego i boljitak društva u cjelini. Iz navedenih se razloga zagovara koncept ekonomije trećeg puta. Ekonomija trećeg puta u prvi plan stavlja socijalnu osjetljivost prema široj društvenoj zajednici. To ne podrazumijeva socijalno pomaganje pojedincima, nego stvaranje uvjeta za postizanje veće pravičnosti u pogledu socijalne i ekonomske osjetljivosti, društveno odgovornim poslovanjem i zaštite životne sredine. Nekada su ostvarena visina profita $i$ tržišnog udjela bili jedino mjerilo uspješnosti poslovanja i dobre pozicije poduzeća na tržištu. Međutim u današnje se vrijeme od poduzeća traži ekološka i socijalna osviještenost što se smatra osnovnim problemom modernog kapitalizma. U skladu s navedenim cilj istraživanja u ovom radu bio je dobiti saznanja pridaju li i u kolikoj mjeri Hrvatska poduzeća važnost socijalnoj osjetljivosti prema svojim zaposlenicima te koliko su izdavanja za socijalna prava radnika povezana sa ostvarivanjem neto profitne marže poduzeća. Istraživanje je provedeno na uzorku od 53 poduzeća koja su registrirana i posluju na području Republike Hrvatske. Empirijskim istraživanjem primjenom matematičkih i statističkih metoda (korelacije i regresije) došlo se do zaključka kako su poduzeća svjesna važnosti socijalne osjetljivosti prema svojim zaposlenicima te takvu poslovnu politiku implementiraju u svoje poslovne strategije. Međutim, došlo se do saznanja kako poduzeća iz promatranog uzorka u dovoljnoj mjeri ne financiraju socijalna prava svojih zaposlenika. Postoji pozitivna linearna povezanost $s$ ostvarivanjem neto profitne marže, dok je koeficijent korelacije izrazito mali.

Ključne riječi: Korporativno upravljanje; Treći put; Ekonomija trećeg puta, socijalna osjetljivost 


\section{UVOD}

Razvoj slobodne tržišne ekonomije kao i globalnog tržišta zahtijevali su razvoj suvremenih načina upravljanja i vođenja kako bi se zadovoljili svi akteri suvremenih poslovnih procesa od vlasnika, preko menadžera do radnika i regulatornih tijela. Voditi poslove suvremenih poduzeća izbjegavajući sukobe interesa uz zakonito izvršavanje svih poslovnih mjera i odluka možemo govoriti o načelima korporativnog upravljanja. Profesionalnu odgovornost svojim poslovnim položajem za to izravno snose članovi uprave, nadzorna ili upravna tijela. To je izrazito teška zadaća naročito kad smo u spoznaji djelovanja slobodnog tržišta i činjenicom da je sve što nije izrijekom zabranjeno dozvoljeno, odnosno sve što nije izrijekom propisano ne mora se primjenjivati. Ta sloboda djelovanja unutar slobodnog tržišta ima svoje obvezujuće aspekte što podrazumijeva da nema prava bez dužnosti niti ovlasti bez osobne odgovornosti. Život pojedinca i svake društvene zajednice zahtjeva neprestano zadovoljavanje niza potreba sudionika u međusobnim odnosima uz odvijanje procesa potrošnje različitih dobara i usluga. U procesu proizvodnje dolazi do posredne ili neposredne povezanosti svih aktera (upravljačkih i/ili nadzornih, izvršnih i regulatornih tijela) preko pojedinačnih sustava (korporacija) u zajednički sustav (tržište). Stoga je praksa korporativnog upravljanja izrazito složen proces uz neophodno poznavanje svih problema u realnom biznis sektoru, praćenjem svakodnevnih procesa unutar kompanija i na tržištu. Ta dinamika tjera organizacije i poslovne ljude da kontinuirano uče i prate nove trendove korporativnog upravljanja prilagođavajući svoje odluke promjenama. U samim procesima korporativnog upravljanja i rukovođenja poslovnim procesima postoje prioriteti, dok opstanak na tržištu zahtjeva od menadžera fokusiranje na ekonomiku poslovanja i postizanje konkurentske prednosti korporacije. Stoga korporativno upravljanje predstavlja toliko kompleksan proces koji obuhvaća profesionalno djelovanje ne samo menadžerske struke, iz područja upravljanja i financija, nego i profesionalno djelovanje pravne struke jer su u korporativnom upravljanju razne interesno utjecajne skupine sklone stvari interpretirati onako kako im u danim okolnostima najbolje odgovara. Korporativno je upravljanje u većem dijelu regulirano Zakonom o trgovačkim društvima koji je usklađen s standardima i direktivama Europske komisije. U skladu s tim donesen je i Hrvatski kodeks korporativnog upravljanja kojim su oblikovani ishodišni temelji za pravila igre u korporativnom poslovanju kapitalnih društava na organiziranim financijskim tržištima. Na takav se način u potpunosti zaokružuju gospodarstveni i institucionalni okviri za izgradnju dobre prakse korporativnog upravljanja na pretpostavkama vladavine prava i društveno odgovornog poslovanja.

\section{POJMOVNO ODREĐIVANJE KORPORACIJE I KORPORATIVNOG UPRAVLJANJA}

Dobra praksa korporativnog upravljanja podrazumijeva složeni proces (poduzetničkog) menadžerskog odlučivanja i upravljanja. Razvojem suvremenog tržišta može se reći da korporativno upravljanje nije jedan od trendovskih tehnika ili znanstvenih metoda organizacije rada i menadžmenta. S vremenom su nastale mnoge definicije korporativnog upravljanja, međutim sam proces korporativnog upravljanja može se razumjeti u potpunosti jedino interdisciplinarnim pristupom koji obuhvaća područje ekonomije, prava, poli- 
tičkih znanosti, etike, filozofske antropologije, politike i sociologije. Pojam korporativnog upravljanja obuhvaća kako interne odnose korporativnog upravljanja i vođenja društvom kapitala, tako i odnose vanjskih nezavisnih interesnih skupina. S obzirom na pojavu velikog broja definicija korporativnog upravlajnja uzet ćemo u obzir OECD-ovo ${ }^{1}$ ishodišno i mjerodavno tumačenje korporativnog upravljanja koje se definira kao skup odnosa između menadžmenta, uprave, dioničara i ostalih interesnih skupina. Nadalje korporativno upravljanje također predstavlja strukturu unutar koje se postavljaju ciljevi poduzeća i određuju sredstva za postizanje tih ciljeva te za praćenje uspješnosti njegova poslovanja (OECD, 2004). Dobro korporativno upravljanje treba pružiti odgovarajući poticaj za upravu i menadžment radi ostvarivanja ciljeva koji su od interesa za društvo i dioničare. Neophodno je osiguravanje transparentnog i efikasnog tržišta koje mora biti usklađeno s vladavinom prava s jasnim naglaskom na podjelu odgovornosti među različitim nadzornim i regulatornim organima u zakonodavnom okruženju s ciljem da se olakša ostvarivanje i zaštite prava svih interesnih skupina u procesu korporativnog poslovanja.

Mnogi autori i istraživači dobre prakse korporativnog upravljanja naglašavaju etičke aspekte i suodgovornost svih stakeholdera za unapređenje kvalitete upravljačkih sustava i ispunjavanje društvene misije korporacija (Barbić i sur., 2008). Dominantna teza govori da se društveno odgovorno poslovanje (Corporate Social Responsability) isplati ekonomski, jer će kompanije koje razviju organizacijsku kulturu i imidž obzirnog, nesebičnog i transparentnog poduzetnika lakše osvojiti povjerenje kupaca, investitora i kreditora te se lakše pozicionirati sa svojim brendovima na globalnom tržištu, ali i imati manje kulturoloških barijera u nastojanjima da postanu dobrodošlo korporativno poduzeće u različitim državama.

\subsection{Poduzeće - korporacija}

U svakodnevnom životu i poslovnom okruženju vlada komunikacijska zbrka. Izraz poduzeće ljudi ne razlikuju od pojma trgovačko društvo ili društvo kapitala te se vlasnika poslovnog uloga uglavnom poistovjećuje s pojmom gazde, većinskog dioničara s poslodavcem, upravljanje s rukovođenjem, kapital s fizičkim novcem (Barbić i sur, 2008). Poduzeće je otvoreni sustav, čvrsto i neodvojivo inkorporiran u složenu mrežu društvenih odnosa, u kojemu se stvara vrijednost koja pokreće našu civilizaciju (Tipurić, 2006, str. 15). Poduzeće je samostalna gospodarska, tehnička i društvena cjelina, s registriranom djelatnošću proizvodnje dobara ili pružanja usluga za potrebe tržišta, u vlasništvu određenog subjekta, čiji menadžment odgovorno upravlja raspoloživim resursima snoseći rizik radi ostvarivanja dobiti i drugih ekonomskih i društvenih ciljeva.

Poduzeće je objekt proučavanja za poduzetnike, koji čini temeljnu gospodarsku jedinicu kao cjelinu za svrsishodno postojanje. Cjelovitost proizlazi iz tehničko-tehnoloških zaokruženosti, a još više kao gospodarska cjelovitost koja za sebe mora ostvariti rezultat dovoljan da pokrije troškove poslovanja poduzeća, uz osiguravanje trajnosti egzistiranja na tržištu te daljnje ponovljene i proširene djelatnosti u budućnosti (Dvorski i sur., 2018). Svrha poduzeća je efikasna uporaba ekonomskih resursa u zadovoljavanju želja i potreba kupaca

1 Organisation for Economic Co-operation and Development 
pa se može reći kako poduzeća ne postoje radi tržišta, nego tržište postoji radi poduzeća. Misija je poduzeća stvoriti kupca i zadovoljiti njegove potrebe bolje od konkurencije (Druker, 2001). Poduzeće treba razvijati sposobnost stvaranja novih potreba kupaca i tržišta kao i razvijanje novih resursa. Posao stvaranja novih proizvoda i usluga sve je teži jer poduzeće mora otkrivati nove načine zadovoljavanja potreba i želja kupaca kao i stvoriti potpuno nove potrebe. Uspješnom poduzetničkom aktivnošću smatra se otkrivanje i iskorištavanje novih mogućnosti za zadovoljavanje potreba kupaca koje drugi nisu primijetili i otkrili.

Najvažnija svrha poduzeća nesumnjivo je ekonomska. Poduzeće kao jedini društveni sustav koji ima svrhu zadovoljavanja želja i potreba šire društvene zajednice, u svakoj odluci i akciji stavlja ekonomsku djelotvornost na prvo mjesto. Poduzeće je ekonomski entitet, skupina razvijenih sposobnosti, kojim se dinamički upravlja sa svrhom ostvarivanja profita. Međutim, poduzeće je i socijalni entitet u kojem se isprepleće čitav niz različitih dimenzija interesnih skupina. Svojevrsna je mreža međuzavisnih ljudi, organizacija i interesa (Tipurić, 2006).

\subsection{Nastanak moderne korporacije}

Moderna korporacija možda je najvažnija društvena inovacija. Bila je krucijalni poticaj ubrzanog ekonomskog rasta, naročito putem mogućnosti iskorištavanja prednosti razmjera i opsega na globalnoj razini. Pokazala se efikasnom u alokaciji resursa, u stvaranju novih tehnologija, proizvoda i usluga te u povećanju produktivnosti (Tipurić, 2008). Mnogi smatraju kako su korporacije nastale kao proizvod privatne poduzetničke inicijative i koncentracije ekonomske moći magnata, one su stvorene kao instrument industrijske politike države. Prvotno su bile u funkciji financiranja velikih kolonizatorskih projekata, a zatim služile kao nositelji razvoja krupne industrije i oblik organiziranja državnih infrastrukturnih djelatnosti. Budući da cijeli sustav tržišne ekonomije kapitalizma počiva na nepisanom društvenom ugovoru da pripadnici poduzetničke industrijske elite mogu zgrtati ogromna bogatstva, uz uvjet da pritom osiguravaju zaposlenost i razuman napredak životnog standarda radnika i građana, država je postupno dala mandat privatnim poduzetnicima da svoja obiteljska poduzeća pretvore u javna društva kapitala i s vremenom, u raznim varijantama društveno ekonomskog uređenja, uvela tripartitni dijalog poslodavaca, sindikata i vlade oko balansiranja interesa u svezi s uvjetima rada, participacije u odlučivanju i odnosa u raspodjeli novostvorene vrijednosti (Barbić i sur., 2008, str. 33). Međutim, ne samo povijesno, nego i zbog praktičnih razloga pravne sigurnosti i razvoja nacionalnog gospodarstva, korporacije su ostale nerazdvojno vezane s državom. U osnovi korporacije imaju pet bitnih zakonskih obilježja (Barbić i sur., 2008, str. 34):

- razdvojenost upravljačke, poslovne i vlasničke funkcije

- razdvojenost imovine, odnosno poslovanja poduzeća koje društvo ima od prava raspolaganja vrijednosnicama društva

- prenosivost vlasništva i prava nad poslovnim udjelima koje imitira društvo kapitala

- državna zaštita opstojnosti poduzeća i njegovih vjerovnika

- obvezna podložnost nezavisnoj vanjskoj reviziji 
Moderna korporacija kao jedna od najbitnijih pojava u ekonomskoj povijesti, termin je koji se odnosi na oblik poduzeća u kojemu vlasnici više nisu osobno odgovorni za obveze niti za bilo kakve druge obligacije koje poduzeće stvara ili može stvoriti, što je dovelo do odvajanja vlasničke funkcije od funkcije upravljanja, odnosno administriranja resursima poduzeća (Means, 2017). Temeljni zahtjev koji se postavlja pred modernu korporaciju stvaranje je bogatstva ključnih interesno utjecajnih skupina na odgovoran način. Kao socijalni sustav s pluralističkim interesima i ciljevima, uz usklađivanje raznovrsnih interesa kako bi se lakše ispunila osnovna ekonomska svrha: etičnosti, odgovornosti i profitabilnosti (Stainer i Stainer, 1998). Korporacije čine više poduzeća različitih gospodarskih djelatnosti te se za takav opseg posla u pravilu prikuplja kapital velikog broja vlasnika kapitala. Glavno je obilježje korporacija da one (njihova poduzeća) obavljaju poslove proizvodnje, prometa, pružanja usluga, investicijskih ulaganja, plasmana kapitala, posredovanja i dr. Korporacije s dislociranim poduzećima u više država u suvremenom gospodarstvu osnova su gospodarske moći najbogatijih zemalja svijeta. Korporacije, kao i poduzeća u privatnom vlasništvu te partnerska poduzeća, imaju određene prednosti i nedostatke koje takav oblik poslovanja čini više ili manje atraktivnim kao odabrani oblik poslovanja (Dvorski i sur., 2018).

\subsection{Definicija korporativnog upravljanja}

Nemoguće je govoriti o upravljanju poduzećem, a ne spomenuti pojam korporativnog upravljanja, koji je u današnje vrijeme dobio veliku pozornost akademske i poslovne javnosti. Cijela ideja korporativnog upravljanja proizlazi iz shvaćanja da postoji društvena odgovornost poduzetnika i da postoje različite interesne skupine (stakeholders) koje imaju legitimno pravo sudjelovati u procesima odlučivanja o radu i poslovanju društva kapitala (Barbić i sur., 2008). Pojam korporativno upravljanje opisuje poslovna pravila, institucionalne ugovore te postupke koji daju odgovor na pitanje tko kontrolira poslovanje korporacija, a tko uživa koristi od tog poslovanja. Tematika korporativnog upravljanja uključuje procese donošenja odluka, a odnose se na interesne skupine poduzeća koje utječu na taj proces. Problem upravljanja koji bi prilikom uspostavljanja korporacije trebalo riješiti jest kreiranje mehanizma za odabir i nadzor menadžera koji stimuliraju korporativno ponašanje među brojnim sudionicima, a destimuliraju određene zlouporabe, gdje se ipak omogućuje dostatna sloboda djelovanja te potiču inovacije i prihvaćanje rizika (Dvorski i sur., 2018).

Korporativno upravljanje bavi se upravljačkim strukturama i procesima u poslovnim sustavima, a možemo ga definirati kao sustav nadzornih mehanizama kojima svi dobavljači krucijalnih inputa trebaju osigurati povrate na svoja ulaganja u korporaciji, ne ugrozivši njezin dugoročni opstanak i prosperitet. Uključuje skup odnosa između menadžmenta, odbora, dioničara i interesno-utjecajnih skupina, definirajući okvir za postavljanje ciljeva i određivanje sredstava za postizanje tih ciljeva, kao i praćenje izvedbe i djelotvornosti poduzeća (Tipurić, 2006). Kvalitetan sustav korporativnog upravljanja rezultira smanjenjem troškova kapitala i efikasnom uporabom resursa od strane poduzeća, dok dobro korporativno upravljanje treba osigurati cjelovite poticaje nadzornom odboru i upravi, kao i menadžmentu svih razina, u ostvarivanju ciljeva koji su u interesu poduzeća i njegovih vlasnika, ako i obvezno uspostavljanje učinkovitog sustava kontrole poslovanja i vođenja poduzeća. 


\subsection{Sustavi korporativnog upravljanja}

Ovisno o presudnom utjecaju na odnose u korporaciji identificiraju se dva temeljna sustava korporativnog upravljanja: otvoreni (angloamerički) i zatvoreni (europskokontitnetalni) sustav. Razlike između otvorenog i zatvorenog sustava jesu u različitim odgovorima na pitanja: koje su najvažnije interesno-utjecajne skupine; koje instrumente i mehanizme pojedina interesno-utjecajna grupa ima na dispoziciji; kako se njima koristi i na koji način sudjeluje u korporativnom upravljanju (Tipurić, 2006). U svakom od tih sustava različito se rješava sustav alokacije socio-ekonomske moći, problem efikasnosti odlučivanja o problemu odnosa menadžmenta i vlasnika.

Hrvatsku karakterizira zatvoreni sustav korporativnog upravljanja. Obilježje sustava je znatna vlasnička koncentracija, s posebnom ulogom vlasnika znatnim paketom dionica koji preuzimaju iznimno aktivnu ulogu u nadzoru i upravljanju korporacijom. Uloga tržišta kapitala znatno je manja nego u otvorenom sustavu, a objavljivanje relevantih informacija ograničeno i nedostatno razvijeno, ali se može konstatirati da se ulaskom Hrvatske u Europsku uniju situacija po tom pitanju znatno poboljšava. Međutim, burze ne funkcioniraju kao tržišta za korporativnu kontrolu kao u otvorenom sustavu.

\subsection{Modeli korporativnog upravljanja}

Kao glavni cilj poslovanja poduzeća u većini slučajeva navodi se maksimiziranje vrijednosti poduzeća iz čega proizlazi zaključak da se u središtu razmatranja takve menadžerske paradigme nalaze interesi vlasnika poduzeća, kao maksimiziranje njihove koristi, odnosno dugoročno maksimiziranje bogatstva vlasnika. Međutim, u suvremenim poslovnim okruženjima u konceptu društveno odgovornog poslovanja javilo se oprečno stajalište čiji su korijeni u socio-ekonomskom promišljanju, socijalna ekonomija. Kao glavni cilj poslovanja postavljeno je maksimiziranje koristi svih interesnih skupina povezanih s poduzećem. Sukladno tome javljaju se dva koncepta korporativnog upravljanja (Dvorski, 2018):

1. Shareholder koncept upravljanja, odnosno pod pojmom shareholder value podrazumijevaju se različiti sadržajni pojmovi od kojih je najvažniji pretpostavka poslovanja i upravljanja orijentirano na vlasnike i na maksimiziranje vrijednosti vlasničkog kapitala. U skladu s tim upravljačke strukture poduzeća trebaju donositi odluke tako da se pozicija vlasnika poduzeća konstantno poboljšava. Vlasnici poduzeća pribavljaju nezaobilazan uvjet obavljanja poslovnih aktivnosti, odnosno kapital te stoga neće financirati ni jedno poduzeće koje im ne garantira adekvatnu sigurnost. Ovim konceptom upravljanja interesi vlasnika temeljni su kriterij upravljanja poduzećem.

2. Stakeholder koncept upravljanja podrazumijeva upravljanje orijentirano prema svim interesno-utjecajnim skupinama unutar poduzeća i skupina povezanih s poduzećem. Koncepcija koja dovodi u pitanje prikladnosti i važnosti maksimiziranja vrijednosti kao cilja poslovanja poduzeća. Sukladno zagovornicima koncepta stakeholder, poduzeće je sastavljeno od velikog broja vanjskih i unutarnjih interesnih skupina poduzeća. Svaka od tih skupina svojim djelovanjem doprinosi općem uspjehu poduzeća, ali jednako tako ima i određene zahtjeve prema poduzeću, odnosno interese. Tako primjerice vlasnici poduzeća imaju interes povećanja bogatstva, vlasnici tuđeg kapitala pravovremeno vraćanje glavnice i kamata, zaposlenici naknade plaće koje odgovaraju 
radnom učinku, menadžment ima interese za većom plaćom, većom moći i utjecajem, dok kupci imaju interes za pristupačnim i kvalitetnim proizvodima, dobavljači pouzdano i redovno naplaćivanje potraživanja te u konačnici javnost ima interes plaćanja poreza i pridržavanja pravnih propisa.

Kao menadžerski ekvivalent teoriji stakeholder javila se metoda upravljanja i mjerenja uspjeha poslovanja pod nazivom balanced scorecard. Balanced scorecard koncept predstavlja skupine ciljeva podijeljene u četiri perspektive: financijsku perspektivu, perspektivu kupaca, perspektivu internih poslovnih procesa te perspektivu učenja i rasta poduzeća (Kaplan i Norton, 1996). Važno je naglasiti da balanced scorecard ne može biti koncept koji može riješiti sukobljene interese različitih skupina u poduzeću. U skladu s navedenim moderno globalno gospodarstvo zahtjeva nove načine upravljanja kako bi se postigla konkurentnost i poduzeća istaknula na globalnom tržištu. Upravo se zbog toga javljaju novi modeli korporativnog upravljanja koje danas nazivamo socijalnom ekonomijom, socijalnim poduzetništvom, ekonomijom trećeg puta.

\section{EKONOMIJA TREĆEG PUTA}

Donedavno se vrlo malo pažnje posvećivalo ulozi privatnog sektora u dokidanju problema siromaštva. Tisućljetni razvojni ciljevi osmišljeni su bez prepoznavanja uloge koju bi privatni sektor mogao igrati. Razvojni program Ujedinjenih naroda posve je usredotočen na zamisli doprinosa privatnog sektora u rješavanju problema siromaštva (UN, 2008). Globalizacija je dovela do novih paradigmi korporativnog upravljanja kako bi se postigla konkurentnost i smanjilo siromaštvo. Stakeholdersko društvo temelji svoje vrijednosti na principu prava i obaveza koji se stvaraju oko ideje ekonomskog, socijalnog i političkog uključivanja. Cilj realizacije tog koncepta izgradnja je slobodnog, moralnog i kohezivnog društva koje se bazira na sveopćem društvenom uključivanju i tržišnoj ekonomiji.

\subsection{Definicija i značenje trećeg puta}

Treći je put političko-ekonomski pristup koji nije ni lijevo ni desno krilo, nije ni kapitalizam ni socijalizam, već nešto između ili kombinacija oboje. Treći put je centristička ekonomska filozofija koja se pojavila i rasla u 1990-ima u Sjedinjenim Državama i Velikoj Britaniji, Europi, a potom i ostatku svijeta. Danas u političko-ekonomskom smislu bilježi sve manje razlika između lijevog i desnog krila te je sve učestalije približavanje politike društva tzv. centru i sve češće čujemo lijevi centar ili desni centran, dok su u stvarnoj praksi razlike jako male. Koncept trećeg puta općenito podrazumijeva alternativu srednji put između dvije krajnosti, pokušava pomiriti politiku ljevice i desnice zagovarajući kombinaciju politike ljevice i desnice. Poznat kao srednji oblik socijalizma i kapitalizma ili novi pojmovi politike i ekonomije.

Bill Clinton i Tony Blair izgradili su Nove demokrate i promovirajući treći put. To je smjer srednjeg puta između neobuzdanog turbo kapitalizma i socijalne države. Treći put izražava novo razumjevanje politike i nastoji ugasiti stare kontraste starog načina upravljanja. Glavna je briga trećeg puta pomoći građanima da pronađu put kroz globalizaciju, kao što su promjene u njihovom osobnom životu u odnosu prema prirodi i okolišu (Giddens, 2005). 
Za formiranje ideje podjednako je zaslužna politička praksa i nastanak novih teorijskih koncepcija. Najznačajniji smisao te teorijske koncepcije njeno je formuliranje osnovnih promjena modernog društva, a njena najznačajnija posljedica je redefiniranje i transformacija socijalne države (Kregar, 2000).

\subsection{Stakeholderski koncept ekonomije trećeg puta}

Povezanost stakeholderskog pristupa s ostalim konceptima kao što su socijalno poduzetništvo i društvena odgovornost poduzeća vrlo je snažna. Treći put postaje sredstvo postizanja socijalne pravde. U globalnom okruženju postavlja se pitanje što čine pojedine korporacije boljima od drugih. Nekada su ostvarena visina profita i tržišnog udjela bili jedino mjerilo uspješnosti poslovanja i dobre pozicije poduzeća na tržištu. Danas to više nije dovoljno. Korporacije se moraju izdići iznad vlastitih interesa i djelovati u korist šire društvene zajednice, svojih zaposlenika, kupaca i dobavljača. Stoga se sve više analizira socijalna osjetljivost poduzeća te njihov utjecaj na okoliš i širu društvenu zajednicu. Analizira se kolika je razina socijalnih troškova, troškova za obrazovanje i podizanje životnog standarda, bez obzira što oni opterećuju poslovanje, ali dugoročno donose socio-ekonomsku korist u širem društvenom okruženju te bolju tržišnu poziciju u konkurentskom okruženju.

Ideja trećeg puta smatra se značajno pozitivnom promjenom poslovnih politika od kojih se zahtjeva stavljanje fokusa na šire društveno okruženje. Ekonomija trećeg puta ne podrazumijeva samo izdvajanje troškova poslovanja za socijalnu pomoć građanima i zaposlenicima, nego edukacije i unapređenje sposobnosti društvene zajednice da se brine za sebe i o svom boljitku i napretku. Međutim u korporativnom načinu upravljanja vrlo često se događa nesklad između individualnog i kolektivnog. U korporativnom poslovanju često se prava pojedinaca stavljaju iznad obaveza te se ujedno i njihove odgovornosti prema poduzeću (državi i/ili široj društvenoj zajednici) zanemaruju. Svjedoci smo kako vrlo često pojedinci traže svoja prava bez ispunjavanja svojih odgovornosti i obaveza sprema sustavu (poduzeću). Stoga zagovaranjem socijalne i ekonomske pravičnosti, ne smiju zanemariti prava i obaveze i jedne i druge strane, organizacije prema pojedincu i pojedinca prema organizaciji, u korporativnom okruženju. U protivnom se mogu dogoditi veliki nesklad i sukobi unutar šire društvene zajednice te nedostatak odgovornosti prema lokalnoj zajednici. Dok se s jedne strane očekuje socijalna osjetljivost od privatnog sektora, s druge strane javni sektor, odnosno javni rashodi nalaze se na granici prihvatljivosti dok se ujedno traži više. Javni sektor treba služiti građanima i zbog toga se sustav socijalne sigurnosti mora prilagođavati promjenama u okruženju. Stoga je ulaganje u znanje i obrazovanje, odnosno podizanje socijalne osviještenosti i društvene odgovornosti svih interesnih skupina, ključni faktor napretka društva u cjelini.

Organizacije kao što su Svjetski ekonomski forum usmjerile su skupine u osmišljavanje rješenja za siromaštvo - bilo da se radi o Forumu za društveno odgovorno poduzetništvo ili korporacije koje su surađivale na borbi protiv gladi u svijetu. Uloga privatnog sektora u dokidanju problema siromaštva kod raznih grupa građanskog društva na različite je načine prihvaćena (Prahalad, 2010, str. 5). Sve se više privatnih poduzeća i organizacija civilnog društva povezuju i zajedničkim naporima uče kako surađivati. Sve je snažnija svijest o potrebi spajanja lokalnog znanja nevladinih organizacija s globalnim dosegom multinacio- 
nalnih kompanija kako bi se osmislila jedinstvena i održiva rješenja. Međutim, ne smije se zanemariti činjenica da ne može sve probleme riješiti privatni sektor, ali može pridonijeti okupljanjem tehničkih i financijskih resursa pomoću umijeća organizacije, odgovornosti i poduzetničkog duha kako bi se što uspješnije riješili socio-ekonomski problemi.

\section{METODOLOGIJA ISTRAŽIVANJA I REZULTATI ISTRAŽIVANJA}

Osnovna ideja ekonomije trećeg puta nastala je kao reakcija na nedostatke kapitalizma slobodnoga tržišta. To su prije svega nesigurnost, polarizacija društva i marginalizacija mnogih društvenih grupa. Kao opća filozofija ili koncept, stakeholderska ekonomija se vraća općim načelima slobode, zajedništva, jednakosti i solidarnosti. Njegove su glavne karakteristike i ciljevi postizanje društvene i ekonomske kohezije, a to se realizira uzajamnošću za sve i uključivanjem svih, s naglaskom na socijalnu ekonomiju.

\subsection{Ciljevi i hipoteze istraživanja}

Ekonomija trećeg puta predstavlja kompromis između kapitalizma slobodnog tržišta i starog socijaldemokratskog modela. Nastoji povezati slobodno tržište, industrijsku demokraciju (participacija na radnom mjestu) te visoke i transparentne socijalne izdatke (država blagostanja). Vrijednosti ekonomije trećega puta su slijedeće: jednakost (inkluzivnost), prava uz odgovornosti (obveze), autoritet uz demokraciju (na participativnom temelju). Drugim riječima svi oni kojih se tiče poslovanje poduzeća imaju pravo utjecati da se unaprijede životni uvjeti i ekonomske aktivnosti, a poduzeća imaju dužnost podržavati njihove napore. Zaposlenici se moraju smatrati najvećom vrijednošću poduzeća. Polazeći od svijesti da obrazovani, inovativni i motivirani zaposlenici predstavljaju najveću vrijednost poduzeća te menadžeri moraju posvetiti veliku pozornost planiranju i razvoju ljudskih resursa.

Istraživanjem za ovaj rad željelo se doći do spoznaje u kolikoj mjeri poduzeća vode socijalnu brigu za svoje zaposlenike te koliko je financiranje socijalnih prava radnika povezano sa ostvarivanjem Neto profitne marže. U skladu s navedenim postavljaju se slijedeće hipoteze:

H1 - poduzeća u Hrvatskoj u značajnoj mjeri vode brigu o socijalnim prava radnika

H2 - poduzeća u Hrvatskoj u značajnoj mjeri financiraju socijalna prava radnika

H3 - financiranje socijalnih prava radnika značajno je statistički povezano s pokazateljem Neto profitne marže

\subsection{Uzorak i metode istraživanja}

Istraživanje je provedeno na uzorku od 53 poduzeća koja su registrirana i posluju na području Republike Hrvatske, dok se pokazatelj neto profitne marže dobio izračunom iz financijskih izvještaja za svako pojedino poduzeće. Podaci iz anketnog upitnika prikupili su se metodom anketiranja, telefonski i putem elektroničke pošte u razdoblju od 5 . travnja 2020. do 25. travnja 2020., dok su financijski podaci preuzeti putem Digitalne komore RH iz financijskih izvještaja na dan 31. prosinca 2018. U obradi podataka koristili su se logički, 
analitički i statistički postupci te su se temeljem utvrđenih spoznaja donijeli zaključci. Za obradu prikupljanih podataka primijenile su se statističke metoda pomoću programa SPSS Statistics 17.0.

\subsection{Analiza rezultata istraživanja}

U nastavku su prikazani dobiveni rezultati istraživanja te je na ukupnom uzorku od 53 poduzeća, anketu su ispunili 52,83\% menadžeri i/ili vlasnici poduzeća, dok su ostale ankete 47,17\% ispunili zaposlenici bez upravljačkih funkcija u poduzeću. Od promatranog uzorka prema veličini najviše je velikih poduzeća $64,15 \%$, zatim srednje velikih poduzeća $20,75 \%$, dok je malih i mikro poduzeća bilo 13,21\% i 1,89\%. Prema djelatnosti, anketnim upitnikom najviše je obuhvaćeno poduzeća koja pripadaju uslužnoj djelatnosti 35,85\%, dok trgovačkoj djelatnosti pripada 5,66\%, industrijskih poduzeća je 30,19\%, dok drugim djelatnostima pripada $28,30 \%$ promatranih poduzeća iz uzorka. Struktura vlasničkog kapitala promatranih poduzeća je sljedeća: domaće privatno vlasništvo 37,74\%, domaće državno vlasništvo $41,51 \%$, te kombinirano domaće i inozemno vlasništvo iznosi $18,87 \%$ i 1,89\% poduzeća iz uzorka.

\section{Graf 1 Poduzeća prema veličini}

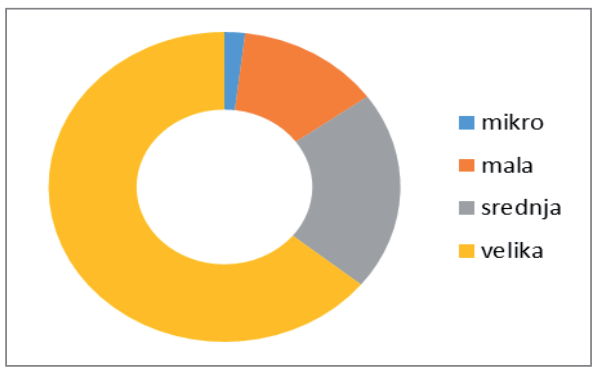

\section{Graf 2 Poduzeća prema djelatnosti}

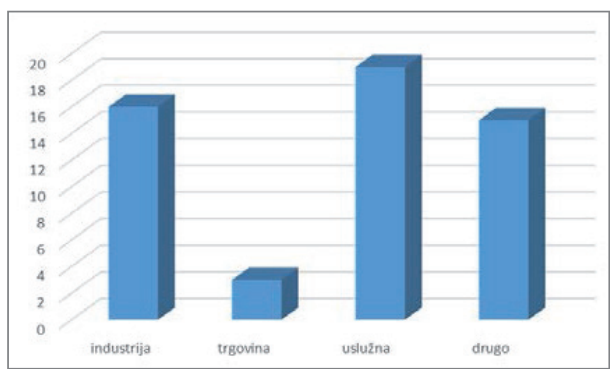

Graf 3 Struktura vlasničkog kapitala promatranih poduzeća

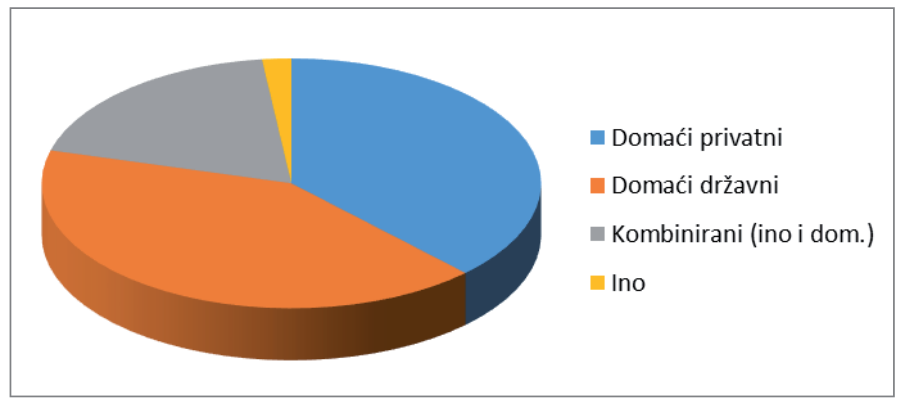

Izvor: Izrada autora 


\section{Graf 4 Stav ispitanika o socijalnoj strategiji poduzeća}

(1-apsolutno se ne slažem, 2-ne slažem se, 3-niti se slažem niti se ne slažem, 4-slažem se, 5-apsolutno se slažem)

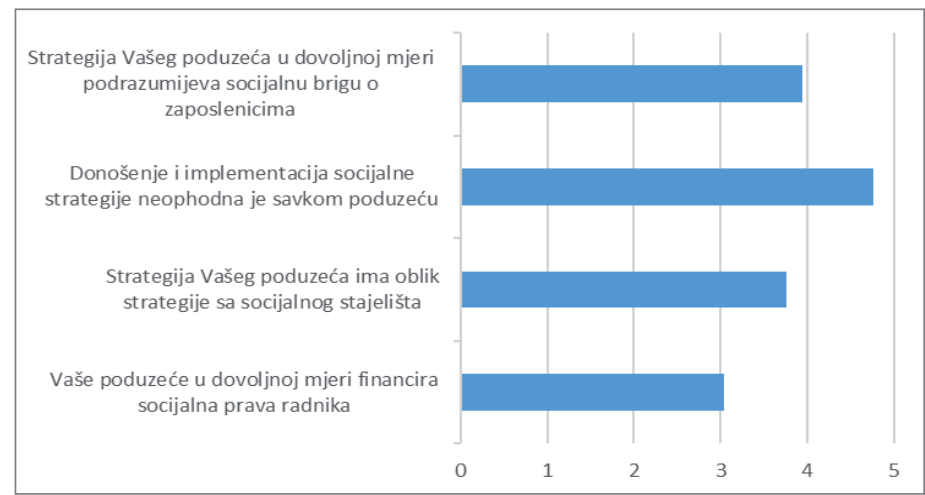

Izvor: Izrada autora

Grafom 4 prikazano je mišljenje ispitanika o poslovnoj strategiji poduzeća usmjerenoj socijalnoj osjetljivosti prema zaposlenicima. Iz provedenog istraživanja vidljivo je kako su strategije promatranih poduzeća u značajnoj mjeri orijentirane socijalnom aspektu približno ocjeni 4, dok ujedno ispitanici smatraju kako je donošenje i implementacija socijalne strategije od izrazite važnosti za poduzeća s visokom prosječnom ocjenom 4,7547. Međutim, kod izdvojenog pitanja u kolikoj mjeri poduzeća financiraju socijalna prava radnika dobivena je prosječna ocjena 3,0377. Iz dobivenih se rezultata može zaključiti kako su poduzeća svjesna važnosti socijalne osjetljivosti prema zaposlenicima, nastoje provoditi socijalni osvještene strategije čime se potvrđuje hipoteza 1. Međutim, socijalna prava radnika lošije se financiraju, iako se financiraju, ali prema mišljnju ispitanika ne dovoljno, iz čega se može zaključiti kako je hipoteza 2 djelomično potvrđena.

\section{Graf 5 Grafički prikaz linearne povezanosti soc. prava radnika sa pokazateljem ROS}

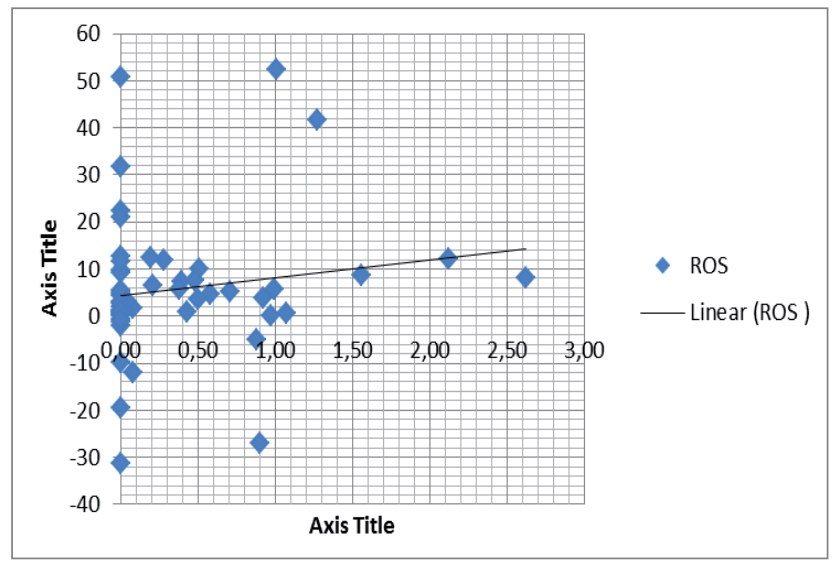

Izvor: Izrada autora 
Iz grafičkog prikaza u grafu 5 vidljiva je pozitivna linearna povezanost između financiranja socijalnih prava radnika i pokazatelja ROS, odnosno ostvarivanjem Neto profitne marže poduzeća.

Izračunala se i prikazala korelacija među varijablama te je u tablici 1 prikazana statistička značajnost povezanosti financiranja socijalnih prava radnika (Soc/S) sa ostvarivanjem neto profitnom maržom (ROS).

\section{Tablica 1 Regresijski model Soc/S i ROS}

\begin{tabular}{|c|c|c|c|c|c|c|c|c|c|c|}
\hline \multicolumn{11}{|c|}{ Model Summary } \\
\hline \multirow{3}{*}{$\frac{\text { Madel }}{1}$} & \multirow[b]{2}{*}{$\mathrm{R}$} & \multirow[b]{2}{*}{ R Square } & \multirow[b]{2}{*}{$\begin{array}{c}\text { Adjusted R } \\
\text { Square }\end{array}$} & \multirow[b]{2}{*}{$\begin{array}{l}\text { Std. Error of } \\
\text { the Estimate }\end{array}$} & \multicolumn{5}{|c|}{ Change Statistics } & \multirow[b]{2}{*}{$\begin{array}{l}\text { Durbin- } \\
\text { Watson }\end{array}$} \\
\hline & & & & & $\begin{array}{l}\text { R Square } \\
\text { Change } \\
\end{array}$ & F Change & df1 & $d f 2$ & Sig. F Change & \\
\hline & $.149^{a}$ & .022 &, 003 & 14,64450 & .022 & 1,159 & 1 & 51 & 287 & 2,006 \\
\hline \multicolumn{11}{|c|}{ a. Predictors: (Constant), Soc_s } \\
\hline
\end{tabular}

Izvor. Izrada autora

Iz koeficijenta korelacije R možemo vidjeti kako povezanost među varijablama postoji, ali je ona izrazito mala. Koeficijent determinacije $R^{2}$ bliži je nuli nego jedinici, stoga ne možemo govoriti o dobroj reprezentativnosti modela. Što se tiče F omjera, možemo vidjeti kako je empirijski F omjer $(1,159)$ veći od teorijske vrijednosti $(0,287)$ te uz danu razinu signifikantnosti 0.05 i uz broj stupnjeva slobode $(1,51)$ dobiveni podaci djelomično potvrđuju hipotezu H3. Financiranje socijalnih prava radnika pozitivno je, ali ne u dovoljnoj mjeri povezano s neto profitnom maržom. Durbin-Watson ima vrijednost oko 2 što indicira na nepostojanje autokorelacije pogrešaka relacije.

\section{ZAKLJUČAK}

Pitanje odgovornog socijalnog ponašanja i ostvarivanja poslovnih ciljeva iniciralo je i teorijske debate o prirodi korelacije između etičkih načela i financijskih rezultata. Maksimiziranje profita kao isključivi cilj korporacije došlo je u sukob sa strategijom moderne korporacije. U novim se okolnostima javio problem šire društvene odgovornosti i osviještenosti ciljeva korporacije prema mnogo širem članstvu, nego što su dioničari. Globalno tržište i sve složenije konkurentsko okruženje zahtjeva od menadžmenta korporacija praćenje novih trendova i zahtjeva šire društvene zajednice. Na teorijskom je planu počela rasprava o potrebi novog pristupa u promišljanju korporacije i njezinih aktivnosti, a naročito u pogledu zaštite socijalno-ekonomskih prava, zaštite okoliša i društveno odgovornog poslovanja.

Iz provedenog istraživanja vidljivo je kako su strategije promatranih poduzeća u značajnoj mjeri orijentirane socijalnom aspektu približno ocjeni 4, dok ujedno ispitanici smatraju kako je donošenje i implementacija socijalne strategije od izrazite važnosti za poduzeća s visokom prosječnom ocjenom 4,7547 čime je potrđena H1 da poduzeća u Hrvatskoj u značajnoj mjeri vode brigu o socijalnim prava radnika. Međutim, kod izdvojenog pitanja H u kolikoj mjeri poduzeća financiraju socijalna prava radnika djelomično je potvrđeno da poduzeća u Hrvatskoj u značajnoj mjeri financiraju socijalna prava radnika s prosječnom ocjenom ispitanika 3,0377. Hipoteza H3 je također djelomično potvrđena, financiranje 
socijalnih prava radnika nije u dovoljnoj mjeri povezano sa ostvarivanjem neto profitnom maržom $(0,149)$, koreliranost iako nije velika, postoji, dok je iz dijagrama rasipanja za promatrane varijable vidljiva pozitivna linearna povezanost. Primjena ekonomije trećeg puta mora prihvatiti globalizaciju, ali za razliku od toga ne smije biti nekontrolirana slobodna trgovina, umjesto toga mora biti usmjerena na konzervativno, tradicionalno, protekcionistički ekonomski pristup koji bi rezultirao dobrom socijalno-ekonomskom praksom. 


\title{
CORPORATE GOVERNANCE AND THE ECONOMY OF THE THIRD WAY
}

\author{
Valentina Vinšalek Stipić, MSc, Senior lecturer \\ Polytechnic "Nikola Tesla" in Gospić \\ Bana Ivana Karlovića 16, 53000 Gospić \\ Phone: +385 53652 305, e-mail: valentinavinsalek@gmail.com
}

\begin{abstract}
The contemporary global environment requires corporate management to apply new ways of managing it to achieve and maintain a competitive advantage. All stakeholders must have a common goal to achieve universal satisfaction. Businesses should no longer have the sole goal of making a profit, but the prosperity of society as a whole. That is the reason for the advocacy of the economy of the third way. The economy of the third way puts social sensitivity for the wider community first. This does not entail social assistance to individuals but the creation of conditions for greater equity in terms of social and economic sensitivity, socially responsible business operations and environmental protection. Some time ago, profit and market share were the only measure of business success and good position of companies in the market. However, businesses are required to have environmental and social awareness, which is considered to be a major problem in modern capitalism. In this paper, it was necessary to find out how much importance Croatian companies give to social sensitivity towards their employees, and how much expenditures for the social rights of workers are related to the net profit margin. The survey was conducted on a sample of 53 companies registered and operating in the Republic of Croatia. Empirical research using mathematical and statistical methods (correlations and regressions) concluded that companies are aware of the importance of social sensitivity to their employees and implement such business policies in their business strategies. However, it was noticed that the companies in the sample do not sufficiently finance the social rights of their employees. There is a positive linear relationship with the realization of the net profit margin, while the correlation coefficient is extremely small.
\end{abstract}

Keywords: Corporate governance; Third way; Economy of the third way 


\section{LITERATURA}

1. Barbić, J., Čolaković, E., Parać, B. i Vujević, V. (2008). Korporativno upravljanje - osnove dobre prakse vođenje društva kapitala. Zagreb: HUM - DROMA.

2. Druker, P. (2001). The Essential Druker. New York: Harper Business.

3. Dvorski, S., Kovšca, V. i Lavković Vincek Z. (2018). Ekonomija za poduzetnike - uvod u poslovnu ekonomiju. Varaždin: TIVA i FOI.

4. Giddens, A. (2005). Odbjegli svijet: Kako globalizacija oblikuje naše živote. Zagreb: Naklada Jesenski Turk.

5. Hrvatski kodeks korporativnog upravljanja. Preuzeto s http://zse.hr/default.aspx?id=10865 (27.01.2020.)

6. Kaplan, R. i Norton, P.D. (1996). The Balanced Scorecard. Boston: Harvard Business School Press.

7. Kregar, J. (2000). Treću put: novi politički i ideološki okvir socijalne politike. Preuzeto s https:// hrcak.srce.hr/file/47338 (03.02.2020.)

8. Means, G. (2017). The Modern Cirporation and Private Property. London: Taylor and Francis.

9. OECD (2004) Principles of Corporate Governance. Preuzeto s http://www.oecd.org/corporate/ ca/corporategovernanceprinciples/31557724.pdf (03.02.2020.)

10. Prahalad, C.K. (2010). Bogatstvo na dnu ekonomske piramide - iskorijevanje siromaštva kroz profit. Zagreb: MATE.

11. Razvojni program Ujedinjenih naroda (2008). Stavaranje koristi za sve: strategije poslovanja sa siromašnima. Preuzeto s https://razvoj.gov.hr/o-ministarstvu/djelokrug-1939/medjunarodnasuradnja/program-ujedinjenih-naroda-za-razvoj-undp/460 (05.02.2020.)

12. Stainer, A. i Stainer, L. (1998). Busuness Performance - a Stakeholder Approach. International Journal of Business Performance Management, 1(1), 14-18.

13. Tipurić, D. (2006). Nadzorni odbor i korporativno upravljanje. Zagreb: Sinergija.

14. Tipurić, D. (2008). Korporativno upravljanje. Zagreb: Sinergija. 